\title{
BUSINESS DECISION MAKING IN CONTEMPORARY ORGANISATIONS
}

\author{
Filip Đoković1 , Jelena Đorđević Boljanović, Dženan Kulović \\ ${ }^{1}$ Faculty of Business in Valjevo, Singidunum University, Valjevo, Serbia \\ ${ }^{2}$ Faculty of Business in Belgrade, Singidunum University, Belgrade, Serbia \\ ${ }^{3}$ Faculty of Economics, University of Zenica, Zenica, Bosnia and Herzegovina
}

\begin{abstract}
:
Investment decision making indicates owners and managers commitment to growth and development of the companies. The nature of the investment decision is complicated, because it must be integrated latest information from external and internal environments including information about real capacities and capabilities. The long-term nature of decisions on investment activities need adequate capital budgeting, which is based on the selection of the optimal sources of financing. Based on assessment of the firm value of the company to decide whether to join an investment or not.
\end{abstract}

\section{Key words:}

business decision making, investment activities, capital budgeting, assessment of firm

This paper is part of the research project "Development of Competitiveness in Serbia's EU Accession Process" No. 47028, 2011-2014, supported by the Ministry of Education and Science of the Republic of Serbia

\section{INTRODUCTION}

A business decision to launch an investment activity demonstrates organisational readiness to develop and grow. Given the changing organisational environment, the investment decision needs to be the result of a systematic and detailed business risk analysis. In order for the investment decision to create a positive context for long-term business results, the owners and managers require a profound insight into the ability and potentials of the organization. Predicting the outcome of an investment decision also involves the assessment of the capacity of the organization to accept the ensuing changes.

A favourable environment is instrumental in creating an investment opportunity. Optimal organisational surroundings, however, do not fall in the domain of realistic economic trends, and the permanent challenge lying ahead of the owners and managers is to discern optimal environmental conditions at a given time.

Modern companies, irrespectively of the size and type of business, tend to develop and grow constantly. The development of a company means a better business performance, which involves tangible improvements in the market, organisational structure and technology. A company grows if it expands the production and service facilities, opens new jobs, increases the existing market share and penetrates new markets. Growth and development are directly proportional to each other, and investment decision making needs to incorporate both dimensions.

\section{INVESTMENT DECISIONS}

In a contemporary business environment, investment decision making involves material and non-material assets alike. Traditionally, the investment decision hinges on material assets, and its purpose is to increase the value of material assets [1]. In the realm of knowledge economy, however, intellectual capital, or non-material assets, is where the decision-maker places an emphasis, adding to the pronounced complexity of investment decision making [2].

The investment decision revolves around return on investment (ROI). It is noteworthy, however, that the owners and managers might perceive it differently. The owner would focus on establishing a favourable yield ratio, aware of the risks inherent in a potential investment decision. The manager, on the other hand, would rather respond to the challenge of creating a strategic framework to produce a favourable yield ratio.

In order to foresee the benefits of the investment decision in the future, the managers need to identify the optimal way to allocate the proceeds of capital investments [3]. Investment decisions may be viewed in the context of an investment project. If the value of the investment project is higher than the planned investment, this is considered to be a positive signal, because the integration and valorisation of the time frame and the risks of future cash flows, define the feasibility of the investment decision and the investment project in its entirety.

The investment decision-maker is aware that a funding decision might be reversed. When it comes to accumulating the funds to support business operations, responsibility for the funding decisions rests with the manager. When a company needs financial support for an investment activity, the managers, in agreement with the owners, might invite investors to provide for cash and, in return, either share the profit directly or in a number of fixed instalments [4].

The choice of funding is vital, and it is exactly what makes the investment decision feasible or not. All investment decisions are strategic in nature, having long-term effects on the performance of the company, which is why the selection of a source of funding is in close correlation with the quality of the investment decision. A wide array of finance choices aside, borrowing appears to be the most obvious one, raising a number of questions for potential investors [5]:

- Should the company issue long-term bonds or take a loan from a bank?

- To what extend is the company supposed to balance between the expected yield and the loan repayment period, in order not to disturb the parameters of its vitality (liquidity, solvency, etc.)?

- What is the most favourable ratio between the profit rate and the interest rate?

- What should the company pledge as collateral?

Having passed and implemented the funding/investment decisions, the management accepted the obligation to pay the 
borrowed funds back in a specified period of time. It is therefore of utmost importance to integrate the liabilities stemming from the choice of funding into all other decisions, lest there should be a conflict of interest within the company.

In making investment and financial decisions, the managers should share the same set of information, emerging from a serious political, economic and technical analysis. Likewise, feedback from the surroundings should complement the knowledge of the relevant industry and its trends.

\section{CAPITAL BUDGETING IN THE CONTEXT OF INVESTMENT DECISION MAKING}

In order for an organisation to identify a realistic need for long-term capital, the prerogative is to have a full picture of its own competence. This is absolutely vital when it comes to the choice of the mode and source of funding.

Capital budgeting, or an investment appraisal, is the planning process to make a rational use of funds for long-term investment initiatives [6]. The capital budgeting process is designed to analyse and forecast the cash flow of individual investment projects, assessing the general financial efficiency, too. [7] Capital budgeting is used in a long-term context only.

The effects of investment decisions call for a complex analysis, which involves a number of factors, from the current position and the company's future alike. In a word of turbulence and uncertainly, it is safe to say that investment decisions are irreversible, as any reconsideration in the future might create considerable costs.

Preventive controls make it possible for the company to avoid the costs of current and subsequent controls, and all relevant factors need to be weighed out in view of preventive controls. Inadequate preventive controls can prolong a payback period to the point of threatening the very existence of the company.

While studying capital investment information it is very important to consider the sectors on the margins of capital investment, the most significant costs of this type being consultancies and development programs for employees.

\section{BUSINESS VALUE ASSESSMENT AND INVESTMENT DECISION MAKING}

To assess the value of a firm is an indispensable step in investment decision making, creating a clear picture of its own sources of funding. In a modern world of business, to assess the value of a company is a necessity. The key reason for the assessment is the value per se, since the company might be offered for sale on the market [8].

From this angle, investment activity in a modern company is viewed in the context of defining and explaining the benefits to the owners of capital. The major issue is whether to use dividends or a capital increase to handle the profit. The principalagent problem might also occur, when the intentions of owners and manager could clash easily over the distribution of the profit.

Investment decision making centres upon the business valuation. Under the Reference [9], the relevant value of a firm is assessed based on a difference between the assessed value of a firm with a project and the assessed value of a firm without one. If the difference is positive the investment will be launched, and vice versa.

To determine the value of a company without a project, the assumption is that the company will not materialize the investment project, suggesting the Liquidation Value (LV), Yield Value (YV) and Net Asset Value (NAV) methods.

\begin{tabular}{ll}
\hline \multicolumn{1}{c}{ Method } & \multicolumn{1}{c}{ Assumption } \\
\hline $\begin{array}{l}\text { Liquidation } \\
\text { Value }\end{array}$ & $\begin{array}{l}\text { No long-term survival for the company, } \\
\text { based on the existing capacity and resources; }\end{array}$ \\
\hline Yield Value & $\begin{array}{l}\text { Yield expected to satisfy the owners, but the } \\
\text { investment will not get off the ground; }\end{array}$ \\
\hline $\begin{array}{l}\text { Net Asset } \\
\text { Value }\end{array}$ & $\begin{array}{l}\text { Yield not expected to reduce the assets, which } \\
\text { will not make the company less attractive if } \\
\text { offered for sale; }\end{array}$ \\
\hline Table 1: Business Valuation Methods
\end{tabular}

Table 1: Business Valuation Methods

Investment decision making shifts the focus to the expected net earnings and the value of the investment. The valuation of a company with a project requires the methods that can display the realistic worth of overall business performance. A Discounted Cash Flow (DCF) valuation is the preferred method.

Under the existing regulations of the Republic of Serbia, the DCF valuation is also the only method applicable. The method is used when projections of realistic future results can be made, the consequences of inflation not included. Income projections are not made for periods under five years, required for the cash flow to stabilise, adding up to the present value.

The next example is of a company without a project: The XY Company's existing line of products has produced results that both the owners and managers find satisfactory. In the last two years the XY Co. reported a net income worth EUR1,200,000. The management estimates say there are no indications the business results might change significantly if no partnership is made with certain potential suppliers. The buyer yield rate is 10 percent.

The value of the company is

$$
\frac{\left(\frac{1200000}{365}\right) \cdot 0,1}{(1+0,1) \cdot\left((1+0,1)^{1 / 365}-1\right)}+\frac{1200000 / 0,1}{1,0485}=12.576 .827 \mathrm{EUR}
$$

The sum of the present value of net income in the projected and residual periods refers to the value of the company with a project. The projected period is ten years. The present net income value implies a consideration of economic trends from the owner's angle. The planned value based exclusively on the company's own resources is presented as the investment. The present value of the investment and expenditure based on a loan will be shown in the text below.

The tables below, displaying the present value of the investment, the loan-based value, and the present net income value from the owner's angle in the projected period, have been modelled after Reference [10].

\begin{tabular}{cccc}
\hline $\begin{array}{c}\text { Date of } \\
\text { Investment }\end{array}$ & $\begin{array}{c}\text { Investment } \\
\text { Amount (EUR) }\end{array}$ & $\begin{array}{c}\text { Discount } \\
\text { Factor }\end{array}$ & $\begin{array}{c}\text { Present Investment } \\
\text { Value (EUR) }\end{array}$ \\
\hline Jan. 31, 2012 & 720.000 & 1,05 & 756.000 \\
\hline March 31, 2012 & 90.000 & 1,02 & 91.800 \\
\hline April 30, 2012 & 90.000 & 1,02 & 91.800 \\
\hline May 31, 2012 & 90.000 & 1,01 & 90.900 \\
\hline June 30, 2012 & 430.065 & 1,00 & 430.709 \\
\hline June 30, 2013 & 56.709 & 0,90 & 51.038 \\
\hline June 30, 2014 & 56.835 & 0,83 & 46.800 \\
\hline Total & 1.533 .609 & & 1.559 .047 \\
\hline
\end{tabular}

Table 2: The present value of the investment to be funded from the company's own sources 
The following table displays the present value of loan-based expenditure:

\begin{tabular}{cccc}
\hline Repayment Date & $\begin{array}{c}\text { Repayment } \\
\text { (EUR) }\end{array}$ & $\begin{array}{c}\text { Discount } \\
\text { Factor }\end{array}$ & $\begin{array}{c}\text { Present Repayment } \\
\text { Value (EUR) }\end{array}$ \\
\hline January 31, 2012 & 282.561 & 0,87 & 245.828 \\
\hline July 31, 2012 & 282.561 & 0,83 & 234.526 \\
\hline January 31, 2013 & 282.561 & 0,80 & 226.049 \\
\hline July 31, 2013 & 282.561 & 0,76 & 214.746 \\
\hline January 31, 2014 & 282.561 & 0,73 & 206.270 \\
\hline July 31, 2014 & 282.561 & 0,69 & 194.967 \\
\hline Total & - & - & 1.322 .386 \\
\hline Total & & & \\
\hline
\end{tabular}

Table 3: Present value of loan-based expenditure

The present value of net income amounts to EUR6,545,634, and the present value in the projected period to EUR7,735,287. Summing up the two results gives us the present net income value in the projected period of EUR14,280,921.

The present net income value in the residual period is EUR4,874,530. The total value of the company with a project is:

\subsubsection{EUR+4.874.530 EUR=19.155.451 EUR}

\begin{tabular}{cc}
\hline Value of the company & Iznos u EUR \\
\hline With project & 19.155 .451 \\
\hline Without project & 12.576 .827 \\
\hline Difference & $\mathbf{6 . 5 4 5 . 6 3 4}$
\end{tabular}

Table 5: Difference between assessed values with and without a project

Since the difference between the assessed values of the company with and without a project is positive, the investment is justified and feasible from an economic point of view. The present net value is equal to the difference, the interpretation being that the internal rate of return does not depend on the economic course of the investment.

\section{CONCLUSION}

Many decisions shape the investment activity in modern companies. The purpose of every investment decision is to increase the value for capital owners. As it happens, it is very difficult to carry out an investment activity based on the company's own capital as a dominant source of funding, which is why the decision makers need to keep reviewing the correlation between their own and borrowed capital.

Having in mind the economic crisis and the global business environment, investment decision making is gaining importance, widely perceived as the answer to unfavourable changes. The underlying purpose of investment decision making is to develop the organisational, financial and human capacity to react properly on market demands.

Investment decision making centres on assessing the value of a company. Based on a difference between the assessed values of the companies with and without a project, a decision can be made whether the investment is feasible or not.

The effects of investment decision making shape the business results, too, the impact they have on external stakeholders notwithstanding. The implementation of investment decisions boosts the growth and development of the company and, by extension, encourages the partners.

\section{REFERENCES}

[1] Ž. Popović, J. Stanković, I. Veselinović, Primena višekriterijumske analize u proceni investicionih projekata, Facta universitatis - series: Economics and Organization, vol. 10, no. 4, 2013, pp. 401-406

[2] J. Đ. Boljanović, Menadžment znanja, Srbija, Beograd, 2009, pp. $12-18$

[3] F. Đoković, Poslovno odlučivanje o investicionim aktivnostima u hotelijerstvu, Strategic management: international journal of strategic management and decision support systems in strategic management, vol. 18, no. 1, pp.

[4] D. Nikolić, Poslovne finansije u hotelijerstvu, Srbija, Valjevo, 2009, pp. 3-7

[5] D. Zipovski, Investiciono odlučivanje, Srbija, Beograd, 2012, pp. 47-52

[6] F. R. Meigs i B. V. Meigs, Računovodstvo: temelj poslovnog odlučivanja, Hrvatska, Zagreb, p. 1223

\begin{tabular}{cccccc}
\hline Year & $\begin{array}{c}\text { Present net income } \\
\text { value (EUR) }\end{array}$ & $\begin{array}{c}\text { Accumulated present net income } \\
\text { value from the owner's angle (EUR) }\end{array}$ & $\begin{array}{c}\text { Net income (EUR) in a } \\
\text { projected period }\end{array}$ & $\begin{array}{c}\text { Discount } \\
\text { factor }\end{array}$ & $\begin{array}{c}\text { Present net income } \\
\text { value (EUR) }\end{array}$ \\
\hline 2013. & 823.752 & 734.133 & 1.200 .000 & 1,05 & 1.144 .437 \\
\hline 2014. & 539.220 & 195.093 & 1.200 .000 & 1,15 & 1.040 .397 \\
\hline 2015. & 735.552 & 567.456 & 1.200 .000 & 1,27 & 945.816 \\
\hline 2016. & 727.884 & 1.295 .430 & 1.200 .000 & 1,40 & 859.833 \\
\hline 2017. & 1.045 .011 & 2.340 .354 & 1.200 .000 & 1,54 & 781.665 \\
\hline 2018. & 950.010 & 3.290 .364 & 1.200 .000 & 1,69 & 710.604 \\
\hline 2019. & 863.646 & 4.154 .010 & 1.200 .000 & 1,86 & 646.005 \\
\hline 2020. & 785.133 & 4.939 .143 & 1.200 .000 & 2,04 & 587.277 \\
\hline 2021. & 713.757 & 5.652 .903 & 1.200 .000 & 2,24 & 533.889 \\
\hline 2022. & 892.731 & $\mathbf{6 . 5 4 5 . 6 3 4}$ & 1.200 .000 & 2,47 & 485.352 \\
\hline Total & - & - & 12.000 .000 & - & $\mathbf{7 . 7 3 5 . 2 8 7}$ \\
\hline
\end{tabular}


[7] S. Orsag, Budžetiranje kapitala: procena investicijskih projekata, Hrvatska, Zagreb, pp. 16-22

[8] S. B. Valčić i B.C.Stumpf, Potreba za približavanjem uporabne i fer tržišne vrijednosti poduzeća u suvremenom pristupu vrednovanju poduzeća, Ekonomska misao i praksa, vol. 22, no.2, pp. 380-381
[9] D. Zipovski, Investiciono odlučivanje, Srbija, Beograd, 2012, pp. 372-373

[10] D. Zipovski, Investiciono odlučivanje, Srbija, Beograd, 2012, pp. 491-493

\section{POSLOVNO ODLUČIVANJE O INVESTICIONIM AKTIVNOSTIMA U SAVREMENIM ORGANIZACIJAMA}

Filip Đoković1, Jelena Đorđević Boljanović ${ }^{2}$, Dženan Kulović ${ }^{3}$

${ }^{1}$ Poslovni fakultet u Valjevu, Univerzitet Singidunum, Železnička 5, Valjevo, Srbija, fdjokovic@singidunum.ac.rs

${ }^{2}$ Poslovni fakultet u Beogradu, Univerzitet Singidunum, Danijelova 32, Beograd, Srbija, jboljanovic@singidunum.ac.rs

${ }^{3}$ Ekonomski fakultet, Univerzitet u Zenici, Travnička 1, Zenica, Bosna i Hercegovina, dzenan.kulovic@unze.ba

\section{Apstrakt:}

Poslovno odlučivanje o investicionim aktivnostima ukazuje na opredeljenost vlasnika i menadžera ka rastu i razvoju preduzeća. Priroda investicione odluke je složena, jer u nju moraju biti integrisane aktuelne informacije iz eksternog i internog okruženja kao i svi podaci koji prikazuju realne kapacitete i sposobnosti organizacije u celini. Dugoročni karakter odluka o investicionim aktivnostima zahteva odgovarajuće kapitalno budžetiranje, koje je zasnovano na odabiru optimalnog izvora finansiranja. U središtu investicionog odlučivanja je procena vrednosti preduzeća na osnovu koje se pristupa investiranju ili se od investiranja odustaje.

\section{Ključne reči:}

poslovno odlučivanje, investicione aktivnosti, kapitalno budžetiranje, procena vrednosti preduzeća. 